\title{
The axis-inducing activity, stability, and subcellular distribution of $\beta$-catenin is regulated in Xenopus embryos by glycogen synthase kinase 3
}

\author{
Cynthia Yost, ${ }^{1,3}$ Monica Torres, ${ }^{2,3}$ Jeffrey R. Miller, ${ }^{2}$ Eugene Huang, ${ }^{2}$ David Kimelman, ${ }^{1}$ \\ and Randall T. Moon ${ }^{2,4}$ \\ ${ }^{1}$ Department of Biochemistry and ${ }^{2}$ Howard Hughes Medical Institute and Department of Pharmacology, University of \\ Washington School of Medicine, Seattle, Washington 98195-7370 USA
}

The serine/threonine kinase Xgsk-3 and the intracellular protein $\beta$-catenin are necessary for the establishment of the dorsal-ventral axis in Xenopus. Although genetic evidence from Drosophila indicates that Xgsk-3 is upstream of $\beta$-catenin, direct interactions between these proteins have not been demonstrated. We demonstrate that phosphorylation of $\beta$-catenin in vivo requires an in vitro amino-terminal Xgsk-3 phosphorylation site, which is conserved in the Drosophila protein armadillo. $\beta$-Catenin mutants lacking this site are more active in inducing an ectopic axis in Xenopus embryos and are more stable than wild-type $\beta$-catenin in the presence of Xgsk-3 activity, supporting the hypothesis that Xgsk-3 is a negative regulator of $\beta$-catenin that acts through the amino-terminal site. Inhibition of endogenous Xgsk-3 function with a dominant-negative mutant leads to an increase in the steady-state levels of ectopic $\beta$-catenin, indicating that Xgsk-3 functions to destabilize $\beta$-catenin and thus decrease the amount of $\beta$-catenin available for signaling. The levels of endogenous $\beta$-catenin in the nucleus increases in the presence of the dominant-negative Xgsk-3 mutant, suggesting that a role of Xgsk-3 is to regulate the steady-state levels of $\beta$-catenin within specific subcellular compartments. These studies provide a basis for understanding the interaction between Xgsk-3 and $\beta$-catenin in the establishment of the dorsal-ventral axis in early Xenopus embryos.

[Key Words: $\beta$-Catenin; phosphorylation; axis formation; Wnt signaling; Xgsk-3; Xenopus development]

Received January 29, 1996; revised version accepted May 2, 1996.

Members of the Wnt family play a major role in regulating cell fate decisions during embryogenesis in vertebrates and invertebrates (McMahon 1992; Nusse and Varmus 1992; Moon et al. 1993b). Drosophila Wnt-1 (wingless; Rijsewijk et al. 1987) signals through an intracellular cascade that includes a novel protein, dishevelled (Klingensmith et al. 1994; Noordermeer et al. 1994; Theisen et al. 1994), a serine/threonine kinase, zw3/ shaggy (Bourouis et al. 1990; Siegfried et al. 1992, 1994), and an intracellular cadherin-binding protein, armadillo (Wieschaus and Riggleman 1987; Riggleman et al. 1989). Genetic evidence in Drosophila indicates that in the absence of a wingless signal, zw3/shaggy antagonizes downstream elements of the wingless pathway via changes in the level of armadillo (Riggleman et al. 1990; Peifer et al. 1991, 1994b). In response to wingless signaling, there is a decrease in the phosphorylation of arma-

\footnotetext{
${ }^{3}$ These authors contributed equally to this work. ${ }^{4}$ Corresponding author.
}

dillo (Peifer et al. 1994a) and an increase in its stability (van Leeuwen and Nusse 1994). These data are consistent with the wingless signaling pathway working through zw3/shaggy to modulate the phosphorylation and stability of armadillo, but to date, there has been no indication of whether $\mathrm{zw} 3 /$ shaggy directly phosphorylates armadillo.

Vertebrate homologs of these genes have been studied most thoroughly in Xenopus laevis. Xenopus eggs contain maternal transcripts encoding the Wnt homologs, Xwnt-5A (Moon et al. 1993a), Xwnt-8b (Cui et al. 1995), and Xwnt-11 (Ku and Melton 1993), a zw3/shaggy homolog, Xgsk-3 (Dominguez et al. 1995; He et al. 1995; Pierce and Kimelman 1995), a dishevelled homolog (Sokol et al. 1995), and the armadillo homolog, $\beta$-catenin (DeMarais and Moon 1992). Overexpression of each of these homologs supports the initial hypothesis (McMahon and Moon 1989) that the Wnt signaling pathway is involved in the formation of the early dorsal-ventral axis (Dominguez et al. 1995; Funayama et al. 1995; He et al. 1995; Pierce and Kimelman 1995; Rothbacher et al. 1995; Sokol et al. 1995). Compelling evidence that this 
pathway is required for specification of this axis was provided by the demonstration that eggs depleted of maternal $\beta$-catenin transcripts do not develop dorsal mesoderm and are unresponsive to ectopic Wnt signals (Heasman et al. 1994). Moreover, expression of a dominantnegative form of Xgsk-3 induces an ectopic dorsal axis, indicating that Xgsk-3 functions in Xenopus to repress downstream components of this pathway (Dominguez et al. 1995; He et al. 1995; Pierce and Kimelman 1995). That these pathways are likely to be conserved among other vertebrate embryos is evident from data that zebrafish embryos also express maternal Wnt and $\beta$-catenin and that overexpression of $\beta$-catenin in zebrafish causes axis duplication as in Xenopus (Kelly et al. $1995 \mathrm{a}, \mathrm{bl}$.

In both Drosophila and Xenopus, $\beta$-catenin emerges as a key downstream component of a Wnt signaling pathway. In this study we have asked whether $\beta$-catenin might be a direct substrate of the putative upstream regulator Xgsk-3. We find that Xgsk-3 can phosphorylate $\beta$-catenin in vitro at an amino-terminal site. Mutant proteins lacking this site have a decreased level of phosphorylation in vivo, enhanced axis-rescuing activity, and greater stability, indicating that Xgsk-3 functions to regulate the levels of $\beta$-catenin within the embryo. Inhibition of Xgsk-3 function with a dominant-negative mutant leads to enhanced levels of $\beta$-catenin within the nucleus, suggesting that the regulation of $\beta$-catenin protein levels within specific subcellular domains may be a consequence of Wnt signaling in vertebrates as in Drosophila (Peifer et al. 1994b).

\section{Results}

Xgsk-3 directly phosphorylates $\beta$-catenin at an amino-terminal site

Although armadillo is genetically downstream of $z w 3$ / shaggy in Drosophila, there have been no biochemical demonstrations that the proteins interact. Suggesting the possibility of interactions, the vertebrate homolog $\beta$-catenin contains a potential glycogen synthase kinase-3 (GSK3) phosphorylation site (Fig. 1A; SGIHSGATTTAPS) that is also present in plakoglobin and armadillo (Peifer et al. 1994a). To test whether $\beta$-catenin is a potential substrate for Xgsk-3, we first purified histidine-tagged versions of Xgsk-3 and $\beta$-catenin after expression in Escherichia coli. In preliminary in vitro kinase assays, recombinant Xgsk-3 phosphorylated $\beta$-catenin, c-jun, and the GS1 peptide (not shown), as reported for mammalian GSK-3 (Boyle et al. 1991; Nikolakaki et al. 1993; Eldar-Finkelman et al. 1995), as well as phosphorylating itself. To test whether the putative Xgsk-3 phosphorylation site present in the first 47 amino acids was required for the in vitro phosphorylation of $\beta$-catenin, this site was deleted in $\Delta \beta$-catenin (Fig. 1A). $\Delta \beta$-catenin is phosphorylated by Xgsk-3 to a lower level than is $\beta$-catenin (not shown), indicating that the first 47 amino acids contain an Xgsk-3 phosphorylation site.

To ensure that the decreased phosphorylation observed with $\Delta \beta$-catenin was solely caused by alterations in the putative Xgsk-3 phosphorylation site, a mutant form of $\beta$-catenin was constructed in which four serine and threonine residues at this site were changed to alanine (pt $\beta$-catenin, Fig. 1A). Multiple residues were altered in this mutant because GSK-3 kinases often phosphorylate multiple residues at their target site (Plyte et al. 1992), and therefore we could not predict exactly which of the residues in $\beta$-catenin would be phosphorylated by Xgsk-3. $\beta$-Catenin and $\mathrm{pt} \beta$-catenin were incubated with Xgsk-3, and aliquots were removed at various intervals. Phosphorylated $\beta$-catenin could be detected after $1 \mathrm{~min}$ of incubation (Fig. 1B, lane 3), with the levels of phosphorylation increasing through the next $24 \mathrm{~min}$ (Fig. 1B, lanes 6,9,14).pt $\beta$-Catenin was phosphorylated at one-third the level of $\beta$-catenin during the first $10 \mathrm{~min}$ and half the level of $\beta$-catenin thereafter (Fig. 1B, lanes $4,7,10,15)$. Interestingly, we observed a mobility shift when wild-type $\beta$-catenin was phosphorylated that was not observed with pt $\beta$-catenin (Fig. 1B). In addition, the level of Xgsk-3 autophosphorylation was reduced when wild-type $\beta$-catenin was present, indicating that $\beta$-catenin can compete with Xgsk-3 as a substrate for phosphorylation (Fig. 1, cf. lanes 6 and 8 ).

Incubation of $\mathrm{pt} \beta$-catenin with Xgsk-3 resulted in a comparable level of phosphorylation to that obtained with $\Delta \beta$-catenin (not shown). These results suggest the existence of an additional Xgsk-3 phosphorylation site. Another potential Xgsk-3 site is located within the amino terminus of $\beta$-catenin (amino acids $112-120$ ) and is present in both $\Delta \beta$-catenin and pt $\beta$-catenin. As this site is not well conserved in armadillo (Riggleman et al. 1989), however, we expect that it is less likely to have a role in Wnt signaling than the site defined here.

To determine whether Xgsk-3 could also phosphorylate $\beta$-catenin in vivo, we injected Xenopus oocytes with RNA encoding Xgsk-3 and myc-tagged versions of $\beta$-catenin or pt $\beta$-catenin (Fig. 1A). Oocytes were chosen for this study because they can be easily metabolically labeled (Smith et al. 1991). Groups of oocytes were injected with synthetic RNA and then incubated in $\left[{ }^{32} \mathrm{P}\right]$-orthophosphate for $5 \mathrm{hr}$. The ectopically expressed $\beta$-catenin was immunoprecipitated by use of an anti-myc antibody, separated on a polyacrylamide gel, and transferred to a nitrocellulose membrane. The amount of ectopic $\beta$-catenin was determined first by Western blotting with an anti-myc antibody, and then the amount of ${ }^{32} \mathrm{P}$ incorporated into $\beta$-catenin was measured with a PhosphorImager. In the first experiment, $\beta$-catenin was labeled to a 30 -fold greater extent than pt $\beta$-catenin (Fig. 1C); in a second experiment, $\beta$-catenin was labeled to a 5 -fold greater extent than pt $\beta$-catenin (Fig. 1C). Significantly, coinjection of a kinase dead mutant of Xgsk-3, dnXgsk-3, which functions as a dominant-negative mutation (Pierce and Kimelman 1995), reduced the labeling of wild-type $\beta$-catenin to the level of phosphorylation observed with pt $\beta$-catenin (Fig. 1C), suggesting that the phosphorylation of pt $\beta$-catenin in these experiments may be caused by other kinases present in the oocyte. Finally, we note that the level of phosphorylated $\beta$-catenin measured in these experiments may be only a frac- 
A B-catenin

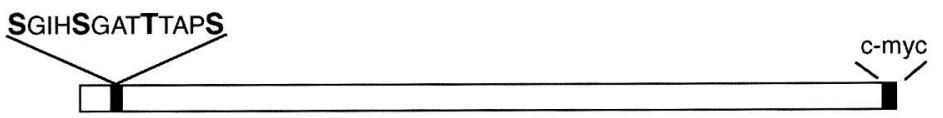

$\Delta ß$-catenin
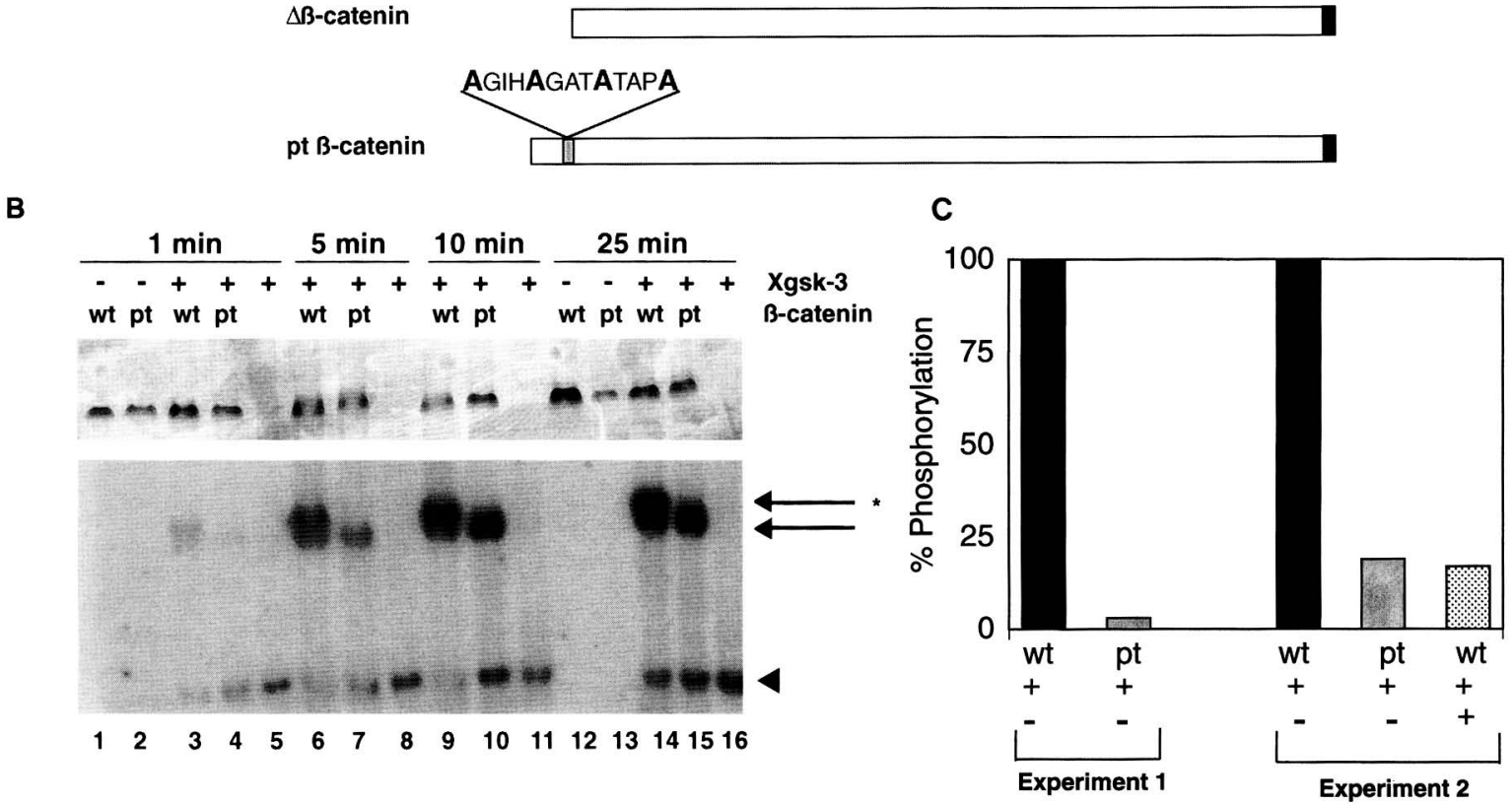

Figure 1. Phosphorylation of $\beta$-catenin by Xgsk-3 in vitro and in vivo. (A) Illustration of $\beta$-catenin constructs used for RNA injections The constructs used for the production of recombinant $\beta$-catenin protein do not contain a c-myc epitope but, instead, contain a histidine tag at the amino terminus. $(B)$ Recombinant and purified histidine-tagged $\beta$-catenin and pt $\beta$-catenin were incubated with $\left\{\gamma^{-}{ }^{32} \mathrm{P}\right\}$ ATP, with or without Xgsk-3, aliquots were taken at 1 (lanes 1-5), 5 (lanes 6-8), 10 (lanes 9-11), and 25 (lanes 12-16) min and then separated on an SDS-polyacrylamide gel. The Coomassie-stained gel (top) and the autoradiograph (bottom) are shown. (Lanes $1,12) \beta$-Catenin without Xgsk-3; (lanes 2,13) pt $\beta$-catenin without Xgsk-3; (lanes 3,6,9,14) $\beta$-catenin with Xgsk-3; (lanes 4,7,10,15) pt $\beta$-catenin with Xgsk-3; (lanes $5,8,11,16$ ) Xgsk-3 alone. Xgsk-3 phosphorylates $\beta$-catenin threefold better than pt $\beta$-catenin at 1,5 , and $10 \mathrm{~min}$ and twofold at $25 \mathrm{~min}$, as well as autophosphorylating (arrowhead). Note the mobility shift (arrow with asterisk) observed with $\beta$-catenin phosphorylation as compared to migration of unphosphorylated $\beta$-catenin and phosphorylated pt $\beta$-catenin (arrow). (C). Oocytes coexpressing $7.5 \mathrm{ng}$ of Xgsk-3 mRNA with $3.5 \mathrm{ng}$ of either myc-tagged $\beta$-catenin or pt $\beta$-catenin mRNA were labeled with $\left[{ }^{32} \mathrm{P}\right]$ orthophosphate, and levels of ${ }^{32} \mathrm{P}$ incorporation were quantified with a PhosphorImager. The histogram depicts ${ }^{32} \mathrm{P}$ incorporation into $\beta$-catenin or pt $\beta$-catenin normalized to the amount of ectoptic $\beta$-catenin or pt $\beta$-catenin as determined by anti-myc Western blotting and densitometry. In experiment 2 , a subset of the oocytes were preinjected with 14 ng of RNA encoding dnXgsk-3.

tion of the $\beta$-catenin labeled during the course of the experiment, as our results (see below) indicate that the phosphorylated form of $\beta$-catenin is rapidly degraded. We conclude that the amino-terminal site that is absent in $\Delta \beta$-catenin and mutant in pt $\beta$-catenin is an in vitro Xgsk-3 phosphorylation site and is necessary for maximal in vivo phosphorylation of $\beta$-catenin. We present evidence below that alterations at this site enhance the axis-inducing activity and stability of $\beta$-catenin in vivo.

\section{Antagonism of embryonic responses to $\beta$-catenin by Xgsk-3 requires the amino-terminal Xgsk-3 phosphorylation site}

The in vitro phosphorylation experiments suggested that the amino-terminal site is important for the regulation of $\beta$-catenin in vivo. Although the Drosophila Xgsk-3 homolog $z w 3 /$ shaggy has been proposed to be a negative regulator of the $\beta$-catenin homolog armadillo, we predicted that if the putative Xgsk-3 phosphorylation site were important, a $\beta$-catenin mutant lacking this site would not be repressed by the endogenous Xgsk-3 in vivo, and therefore, would have greater biological activity.

Injection of RNA encoding $\beta$-catenin (Funayama et al. 1995; Table 1), or the related protein plakoglobin (Karnovsky and Klymkowsky 1995), into the ventral side of Xenopus embryos induces a secondary dorsal axis. We employed a similar assay in which RNA was injected into embryos whose endogenous axis-forming ability was ablated by irradiation with UV light (Malacinski et al. 1977; Scharf and Gerhart 1980). The advantage to this 
Table 1. Antagonism of embryonic responses to B-catenin by Xgsk-3

\begin{tabular}{|c|c|c|c|c|c|c|}
\hline \multirow[b]{2}{*}{$\begin{array}{l}\text { RNA } \\
\text { injected }\end{array}$} & \multicolumn{3}{|c|}{$+X g s k-3$ RNA } & \multicolumn{3}{|c|}{$+\beta$-galactosidase RNA } \\
\hline & $\begin{array}{l}\text { single } \\
\text { axis }\end{array}$ & $\begin{array}{l}\text { double } \\
\text { axis }\end{array}$ & $n$ & $\begin{array}{l}\text { single } \\
\text { axis }\end{array}$ & $\begin{array}{l}\text { double } \\
\text { axis }\end{array}$ & $n$ \\
\hline & $84 \%$ & $5 \%$ & 62 & $2 \%$ & $96 \%$ & 53 \\
\hline$\Delta \beta$-catenin & $5 \%$ & $93 \%$ & 55 & $4 \%$ & $96 \%$ & 55 \\
\hline
\end{tabular}

Embryos were coinjected into the ventral marginal zone with $\beta$-catenin RNA $(0.2-1 \mathrm{ng})$ mixed with $X g s k-3$ or $\beta$-galactosidase RNA (5 ng) at the four-cell stage, and scored for the development of a single or double axis at tailbud or tadpole stages. (n) Numbers of embryos scored over the course of several experiments. The $\beta$-catenin genes employed in this analysis were chimeric with green fluorescent protein, which does not affect the signaling activity of the protein (data not shown).

assay is that the results can be measured quantitatively by use of the dorsoanterior index (DAI; Kao and Elinson 1988), where a score of 0.0 indicates a completely ventralized embryo and a score of 5.0 is a completely normal embryo. Scores higher than 5.0 indicate hyperdorsalized embryos. Recently, this assay was used to demonstrate that $\beta$-catenin can induce an ectopic axis in UV-irradiated embryos (Guger and Gumbiner 1995).

As shown in Figure 2A, $\Delta \beta$-catenin was more effective at rescuing a dorsal axis than wild-type $\beta$-catenin when the same amounts of RNA were compared. Both $\Delta \beta$-catenin and wild-type $\beta$-catenin were able to rescue the embryonic axis completely at higher doses of RNA, although $\Delta \beta$-catenin produced this effect at a lower level of injected RNA than did wild-type $\beta$-catenin (not shown). Similarly, pt $\beta$-catenin was found to be more active than wild-type $\beta$-catenin in this assay (Fig. $2 B$ ). These results demonstrate that the in vitro Xgsk-3 phosphorylation site functions to inhibit the axis-inducing activity of $\beta$-catenin in the Xenopus UV-rescue assay.
We expected that the wild-type $\beta$-catenin was less active in the UV-rescue assay than $\Delta \beta$-catenin or pt $\beta$-catenin because it was negatively regulated by the endogenous Xgsk-3 at the amino-terminal site, unlike the mutant proteins. As the level of ectopically expressed $\beta$-catenin increases, it might be expected to overcome the inhibitory effect of the endogenous Xgsk-3. This could explain why high levels of ectopic wild-type $\beta$-catenin will completely rescue a UV-irradiated embryo (Guger and Gumbiner 1995; data not shown) and induce a secondary axis in unirradiated embryos (Funayama et al. 1995). If Xgsk-3 is involved in the negative regulation of $\beta$-catenin and it becomes limiting when $\beta$-catenin is highly overexpressed, then expression of additional Xgsk-3 should be able to reduce or block the axis-inducing activity of high levels of ectopic wild-type $\beta$-catenin, but not a mutant form of $\beta$-catenin lacking the Xgsk-3 phosphorylation sites.

We asked whether injection of RNA encoding active Xgsk-3 would block axis duplication in response to ectopic expression of $\beta$-catenin in Xenopus embryos, an assay previously employed to define the activities of both $\beta$-catenin (Funayama et al. 1995) and Xgsk-3 (Dominguez et al. 1995; He et al. 1995; Pierce and Kimelman 1995). As summarized in Table 1 , coinjection of a mixture of $\beta$-galactosidase RNA with either $\beta$-catenin RNA or $\Delta \beta$-catenin RNA into the ventral marginal zone of four-cell embryos caused duplication of the embryonic axis in $96 \%$ of the embryos. Strikingly, a greater than or equal to fivefold excess of Xgsk-3 RNA mixed with $\beta$-catenin RNA promoted duplication of the axis in only $5 \%$ of the embryos, whereas the construct lacking Xgsk-3 phosphorylation sites, $\Delta \beta$-catenin, caused duplication of the axis in $93 \%$ of the embryos. We conclude that Xgsk-3 negatively regulates an embryonic response to ectopic $\beta$-catenin, duplication of the axis, and that this negative regulation requires the amino-terminal Xgsk-3 phosphorylation site of $\beta$-catenin.
A

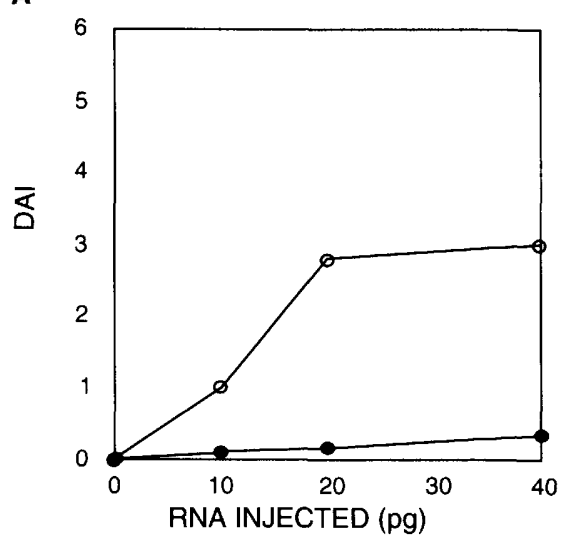

B

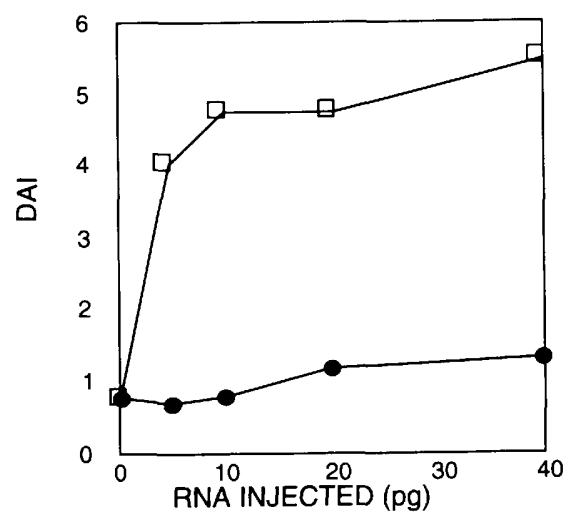

C

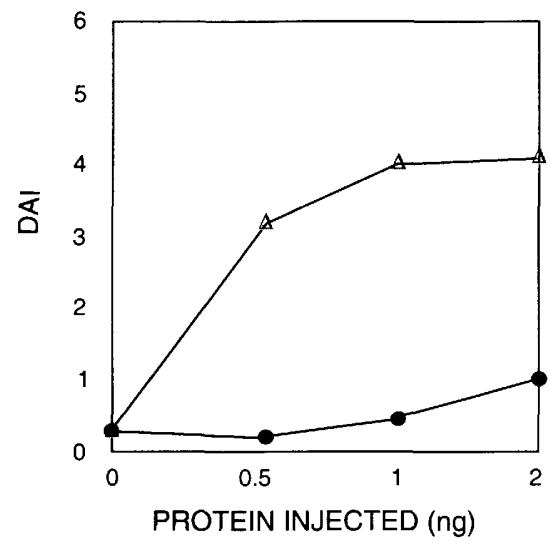

Figure 2. Phosphorylation-defective $\beta$-catenin is more active at inducing a dorsal axis than wild-type $\beta$-catenin after expression in UV-irradiated Xenopus embryos. Embryos were irradiated with UV light and injected with either RNA encoding wild-type $\beta$-catenin $(O)$ or $\Delta \beta$-catenin $(O)(A)$, wild-type $\beta$-catenin $(O)$ or pt $\beta$-catenin $(\square)(B)$, or injected with recombinant $\beta$-catenin $(\Theta)$ or pt $\beta$-catenin protein $(\triangle)(C)$. Embryos were scored by the dorso-anterior index (DAI) at the tadpole stage. DAI $=5$ corresponds to a wild-type embryo; $\mathrm{DAI}=0$ is a fully ventralized embryo. DAI scores $>5$ represent hyperdorsalized embryos. Each data point represents $16-45$ embryos. 


\section{Xgsk-3 regulates the stability of $\beta$-catenin in embryos}

Although the above experiments indicate that mutations in $\beta$-catenin that reduce its phosphorylation by Xgsk-3 lead to greater activity and to reduced negative regulation by Xgsk-3, these experiments do not distinguish between the possibilities that wild-type $\beta$-catenin is less active than the phosphorylation-defective forms or is less stable, and hence less available, to participate in signaling activities. To address this issue, we prepared protein extracts from sibling embryos used in the above experiments (Fig. 2B) and measured the level of $\beta$-catenin translated from injected RNAs. Proteins were extracted from nonirradiated embryos (Fig. 3A, lanes 1-3) and from

A

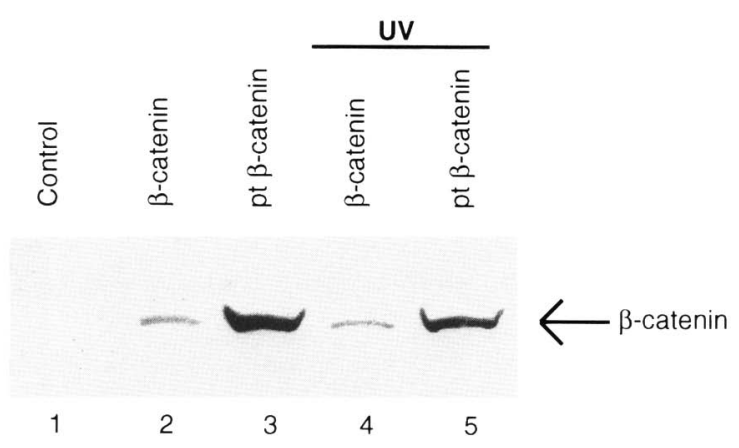

B

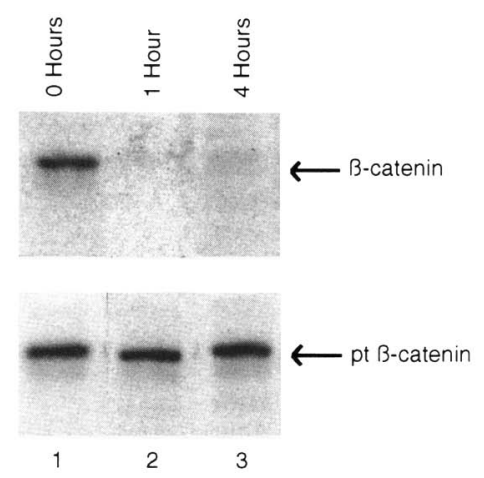

Figure 3. pt $\beta$-Catenin is more stable in embryos than wildtype $\beta$-catenin. $(A)$ Immunoblot with anti-c-myc antibody and proteins extracted from embryos shown in Fig. 2B demonstrates that phosphorylation-defective $\beta$-catenin accumulates to greater levels than wild-type $\beta$-catenin in vivo. (Lane 1) Uninjected controls; (lanes 2,3) embryos injected with $\beta$-catenin (2) or $p t \beta$-catenin (3) mRNA; (lanes 4,5) embryos exposed to UVirradiation and injected with $\beta$-catenin (4) or pt $\beta$-catenin (5) mRNA. $(B)$ pt $\beta$-Catenin protein is more stable than wild-type $\beta$-catenin protein. $\beta$-catenin or pt $\beta$-catenin RNAs were translated in a rabbit reticulocyte lysate. Equivalent volumes of lysate containing equivalent levels of $\left[{ }^{35} \mathrm{~S}\right]$-methionine-labeled $\beta$-catenin products were injected into the animal pole of both blastomeres of two-cell stage embryos. Wild-type $\beta$-catenin protein degrades rapidly, as it is only detectable in immunoprecipitations from protein extracts prepared immediately after injection (lane 1). In contrast, pt $\beta$-catenin protein is stable, as its levels do not change at 1 or $4 \mathrm{hr}$ after injection (cf. lane 1 to lanes 2 and 3$)$.
UV-irradiated embryos (lanes 4,5) $8 \mathrm{hr}$ after the injection of RNA and analyzed on Western blots, taking advantage of a myc epitope tag present on the carboxy-terminal end of the ectopic $\beta$-catenin proteins (Fig. 1A) to distinguish ectopic from endogenous $\beta$-catenin. With or without $\mathrm{UV}$-irradiation, greater levels of $\mathrm{pt} \beta$-catenin relative to ectopic wild-type $\beta$-catenin were detected after injection of these RNAs.

Because the first step in the immunoprecipitation assay is the removal of insoluble material, we also examined this fraction for the presence of myc- $\beta$-catenin by solubilizing it in SDS to ensure that wild-type and pt $\beta$-catenin did not simply fractionate differently. Negligible myc- $\beta$-catenin was observed in the insoluble material (not shown). We also employed Western blot analysis with anti- $\beta$-catenin antibodies to measure the total levels of $\beta$-catenin in embryos injected with various $\beta$-catenin RNAs. We did not observe a perceptible increase in the overall level of $\beta$-catenin relative to controls (not shown).

These results raised the possibility that the different activities of the $\beta$-catenins might be caused by a higher level of synthesis of pt $\beta$-catenin relative to wild-type $\beta$-catenin from the injected RNAs. Although the DNA constructs used to produce both forms of $\beta$-catenin RNA are virtually identical, with the exception of four substituted alanines in pt $\beta$-catenin, we compared the activities of injected recombinant wild-type and pt $\beta$-catenin polypeptides to rule out potential differences in translation. As shown in Figure 2C, pt $\beta$-catenin was more active in rescuing a dorsal axis than wild-type $\beta$-catenin polypeptide, demonstrating that the differences in activity between these two forms of $\beta$-catenin in Figure $2 B$ cannot be attributable to differences in their synthesis.

The alternative possibility, that wild-type $\beta$-catenin is less stable than pt $\beta$-catenin, was directly tested. Both proteins were synthesized in vitro with ${ }^{35} \mathrm{~S}$ incorporated in a rabbit reticulocyte extract, and comparable levels (Fig. 3B, lane 1) were injected into Xenopus embryos. Whereas wild-type $\beta$-catenin was degraded $1 \mathrm{hr}$ after injection of the extract (Fig. 3B, lane 2), the levels of pt $\beta$-catenin were not altered within $4 \mathrm{hr}$ (Fig. 3B, lanes $1-3$ ). These results indicate that the amino-terminal site is important for the stability of $\beta$-catenin.

If the differences in $\beta$-catenin levels were attributable to the activity of endogenous Xgsk-3 acting on the ectopic $\beta$-catenin, then inhibition of the endogenous Xgsk-3 should specifically increase the accumulation of ectopic wild-type $\beta$-catenin but not either of the mutant forms of $\beta$-catenin. To test this, the steady-state levels of myc-tagged $\Delta \beta$-catenin, pt $\beta$-catenin, and wild-type $\beta$-catenin were measured $4 \mathrm{hr}$ after coinjection of RNAs encoding these proteins into Xenopus embryos with RNAs encoding either wild-type Xgsk-3, dominant-negative Xgsk-3 (dnXgsk-3), or frame-shifted sonic hedgehog (fshh) as an injection control. Western blot analyses revealed that ectopic wild-type $\beta$-catenin protein levels were reproducibly higher in embryos coexpressing dnXgsk-3 mRNA (Fig. 4, lane 4), relative to that observed in embryos coexpressing wild-type Xgsk-3 mRNA (Fig. 4, 
lane 3) or fshh (lane 2). We only observed negligible effects of ectopic expression of dnXgsk-3 on accumulation of ectopic $\Delta \beta$-catenin (Fig. 4, cf. lane 7 with lanes 5 and 6 ), or pt $\beta$-catenin (Fig. 4, cf. lane 10 with lanes 8 and 9), indicating that the inhibition of endogenous Xgsk-3 has no effect on the accumulation of $\beta$-catenin mutant polypeptides lacking the amino-terminal site. As the overexpression of wild-type Xgsk-3 had no effect on wild-type $\beta$-catenin levels relative to $f s h$-injected controls (Fig. 4, cf. lane 3 with 2), this indicates that the activity of endogenous Xgsk-3 is saturating with respect to the levels of ectopic $\beta$-catenin used in this experiment. We conclude that the negative regulation of $\beta$-catenin activity by Xgsk-3 occurs at least in part through Xgsk-3 enhancing the degradation of $\beta$-catenin.

\section{Xgsk-3 modulates the accumulation \\ of endogenous $\beta$-catenin in nuclei}

Several lines of data led us to suspect that Xgsk-3 might, in part, block the signaling activity of $\beta$-catenin through modulation of its subcellular distribution, including evidence that the ectopic expression of $\beta$-catenin leads to detectable accumulation in nuclei (Funayama et al. 1995 ). Because it is possible that the nuclear localization of $\beta$-catenin was an artifact of its ectopic expression, we asked whether endogenous $\beta$-catenin was present in nuclei and whether this could be modulated by Xgsk-3. Indirect immunofluorescence with polyclonal antibodies that we raised to a bacterially expressed $\beta$-catenin fusion protein (McCrea et al. 1993) was used in conjunction with low-light video imaging to detect endogenous $\beta$-catenin in entire animal caps of gastrula-stage embryos. This explant was employed because the stage 10 animal cap was thinned to a few cells deep, allowing an analysis of what is essentially an intact epithelial layer, with normal cell junctions.

Preincubation of the antibody with the glutathione $S$-transferase (GST) fusion protein blocks the fluorescent signal (Fig. 5A), although unblocked antibody clearly stains the perimeter of the cells as well as nuclei (Fig. 5B). Using software in the low-light video imaging system to set the threshold for fluorescence detection to be equivalent to the membrane staining, we established that the nuclear staining was less intense than the membrane staining in $64 \%$ of the cells (Table 2).

The general pattern of staining and the lower level of nuclear relative to membrane staining for endogenous $\beta$-catenin was unaffected by prior injection of Xgsk-3 RNA (Fig. 5C; Table 2). We attribute this lack of effect to the likelihood that endogenous Xgsk-3 activity is present in these cells; hence, increasing the levels does not have much effect. In contrast, the injection of RNA encoding dnXgsk-3 has a clear effect on the localization of endogenous $\beta$-catenin, causing the nuclei to stain more strongly than cell membranes in many cells (Fig. 5D; Table 2). When the levels of staining were quantified, the nuclei were found to stain more strongly than cell membranes in only $15 \%$ of uninjected explants and in only $9 \%$ of explants from embryos injected with Xgsk-3 RNA, but this increased to $49 \%$ in embryos injected with dnXgsk-3 RNA. These data demonstrate that concomitant with the modulation of $\beta$-catenin stability, Xgsk-3 alters the accumulation of $\beta$-catenin in distinct subcellular compartments.

\section{Discussion}

We have presented evidence that Xgsk-3 functions as a direct negative regulator of the dorsal axis-inducing activity of $\beta$-catenin in Xenopus embryos. This negative regulation occurs concomitant with Xgsk-3 decreasing the stability of $\beta$-catenin polypeptides as well as modulating its subcellular distribution. We find that an amino-terminal motif present in $\beta$-catenin, plakoglobin, and armadillo (Peifer et al. 1994a) is a site of $\beta$-catenin phosphorylation by Xgsk-3 in vitro. Elimination of this site, by either truncation or by amino acid substitutions,
Figure 4. dnXgsk-3 increases the steadystate levels of wild-type $\beta$-catenin but not the $\beta$-catenin mutants. Immunoblot with anti-c-myc antibody monitoring steadystate levels of $m y c$-tagged $\beta$-catenin, $\Delta \beta$-catenin, and pt $\beta$-catenin coexpressed with fshh, Xgsk-3, or dnXgsk-3 in Xenopus embryos. Each RNA was injected into the embryos (see Materials and methods). (Lane 1) Uninjected controls; (lanes 2-4) $\beta$-catenin mRNA coinjected with $f$ shh $(2), X g s k-3(3)$, or dnXgsk-3 (4) mRNA; (lanes 5-7) $\Delta \beta$-catenin mRNA coinjected with $f s h$ (5), Xgsk-3 (6), or $d n X g s k-3$ (7) mRNA; (lanes 8-10) pt $\beta$-catenin RNA coinjected with fshh $|8|$, Xgsk-3 (9), or dnXgsk-3 (10) mRNA. Inhibition of endogenous Xgsk- 3 activity by overexpressing dnXgsk-3 increases $\beta$-catenin steady-state levels but has no effect on phosphorylation-defective $\Delta \beta$-catenin and $\mathrm{pt}$ $\beta$-catenin.

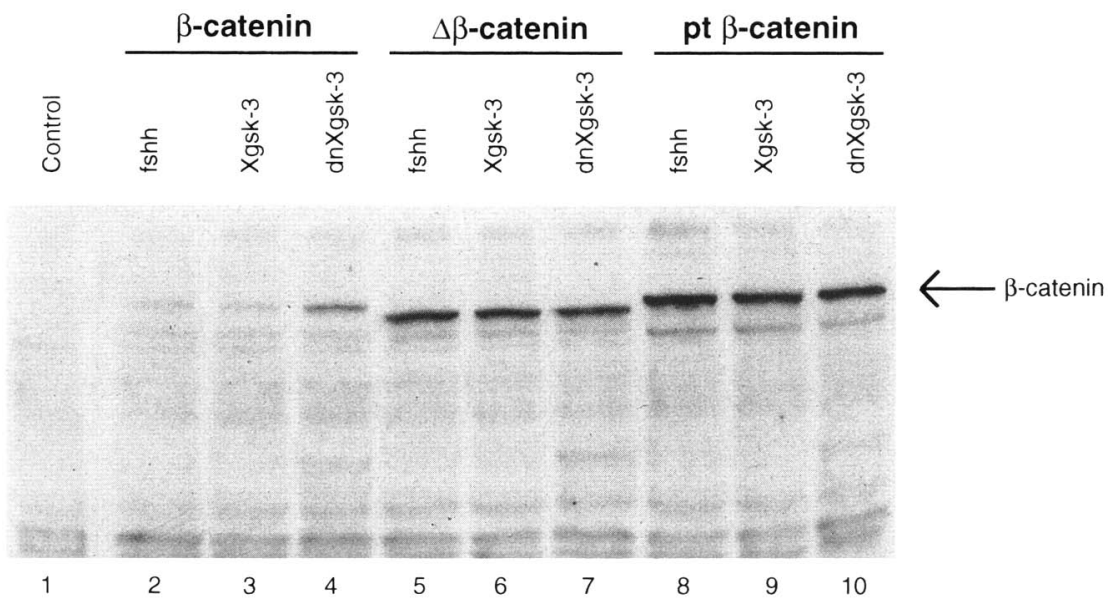



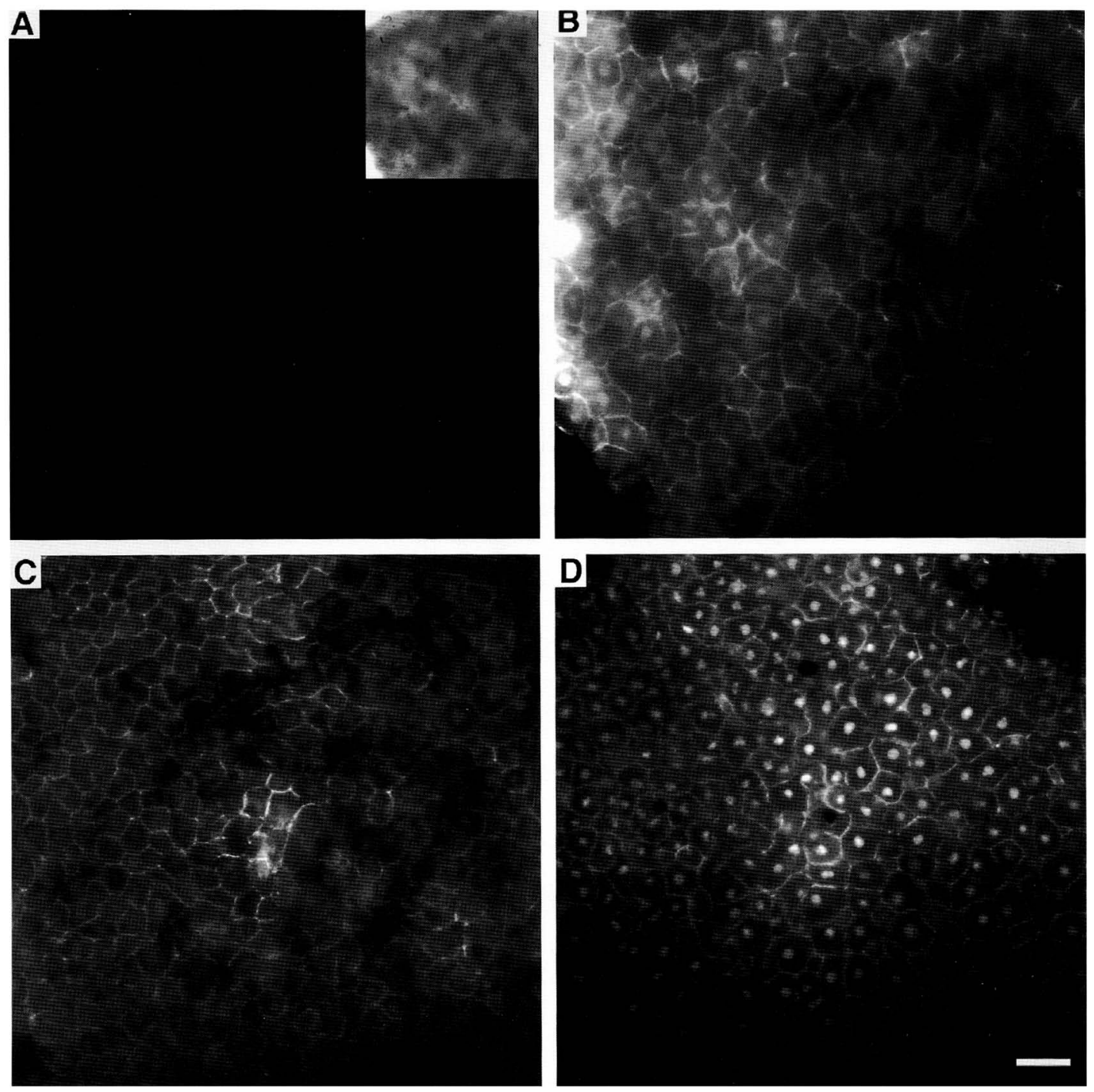

Figure 5. Immunofluorescent localization of endogenous $\beta$-catenin and its regulation by Xgsk-3 and dnXgsk-3. Animal caps of gastrula-stage embryos were immunolabeled with anti- $\beta$-catenin rabbit polyclonal serum and a CY-5-conjugated secondary antibody; then low-light video imaging was conducted as described in Materials and methods. $|A|$ Uninjected animal cap incubated with anti-serum that was preabsorbed with $\beta$-catenin-GST fusion protein. (Inset) The bright-field image of this cap; $(B)$ uninjected animal cap; $(C)$ animal cap of an embryo injected with $2.5 \mathrm{ng}$ of Xgsk-3 mRNA into the animal hemispheres of each blastomere at the two-cell stage; $(D)$ animal cap of an embryo injected with $2.5 \mathrm{ng}$ of $d n X g s k-3 \mathrm{mRNA}$ into the animal hemispheres of each blastomere at the two-cell stage. Scale bar in D, $50 \mu \mathrm{m}$.

decreases both the in vitro and in vivo phosphorylation of $\beta$-catenin and increases the dorsalizing activity of ectopic $\beta$-catenin in UV-irradiated embryos. These results are consistent with the hypothesis that endogenous Xgsk- 3 directly phosphorylates the ectopic $\beta$-catenin and thereby inhibits its activity. Elimination of the in vitro Xgsk-3 phosphorylation site removes this negative control, causing ectopic $\beta$-catenin to be more active as a dorsalizing agent.

A $\beta$-catenin mutant lacking the Xgsk-3 phosphorylation site would be expected to be insensitive to the addition of ectopic Xgsk-3. This was demonstrated by ectopically expressing Xgsk-3 along with wild-type and $\Delta \beta$ - catenin on the ventral side of embryos. Whereas the ability of wild-type $\beta$-catenin to induce a secondary axis was suppressed by the ectopic Xgsk-3, the mutant $\beta$-catenin was not affected.

Ectopic expression of wild-type $\beta$-catenin will induce a dorsal axis (Table 1; Funayama et al. 1995). Our results indicate that for this induction to occur, wild-type $\beta$-catenin must be supplied in sufficiently high levels so that it can overcome the repressing effects of the endogenous Xgsk-3. We hypothesize that $\beta$-catenin mutants can induce a dorsal axis at a lower level of injected RNA or protein because they are not affected by the endogenous Xgsk-3. Furthermore, we propose that the dominant-neg- 
Table 2. Xgsk-3 modulates the accumulation of endogenous $\beta$-catenin

\begin{tabular}{lccccc}
\hline \multirow{2}{*}{$\begin{array}{l}\text { RNA } \\
\text { injected }\end{array}$} & \multicolumn{5}{c}{ Nuclear/membrane ratio $(\%)$} \\
\cline { 2 - 6 } & \multicolumn{1}{c}{$<$} & \multicolumn{1}{c}{1} & \multicolumn{1}{c}{1} & \multicolumn{1}{c}{$>$} & \multicolumn{1}{c}{$n$} \\
\hline None & 10 & 64 & 11 & 15 & 614 \\
Xgsk-3 & 14 & 69 & 8 & 9 & 1324 \\
dnXgsk-3 & 7 & 30 & 15 & 49 & 1233 \\
\hline
\end{tabular}

RNAs ( $2.5 \mathrm{ng}$ ) encoding the proteins denoted were injected into the animal hemispheres of each blastomere at the two-cell stage, and the animal caps of gastrula-stage embryos were analyzed for $\beta$-catenin localization by fluorescence microscopy. $(n)$ The number of cells stored. The nuclear/membrane ratio of fluorescence was established by setting the plasma membrane fluorescence as the threshold and monitoring the relative fluorescence of nuclei by low-light video imaging as described in $\mathrm{Ma}$ terials and methods.

ative mutant of Xgsk-3 is able to induce a dorsal axis by preventing the endogenous Xgsk-3 from regulating the endogenous $\beta$-catenin, thereby permitting the $\beta$-catenin to function as a dorsalizing agent.

\section{Xgsk-3 regulation of $\beta$-catenin stability}

Our results indicate that Xgsk-3 modulates the dorsalizing activity of $\beta$-catenin at least in part by decreasing the stability of the $\beta$-catenin polypeptide. We have shown here that ectopic expression of wild-type $\beta$-catenin RNA results in a lower level of $\beta$-catenin protein than does expression of either of the two $\beta$-catenin mutants. Furthermore, the levels of in vitro-synthesized wild-type $\beta$-catenin are substantially reduced within $1 \mathrm{hr}$ of injection, whereas the levels of pt $\beta$-catenin remain stable for at least $4 \mathrm{hr}$. These results suggest that the increased activity of the mutant $\beta$-catenin polypeptides can be explained, at least in part, by their higher levels of accumulation. In support of this hypothesis, we show that bacterially expressed $\Delta \beta$-catenin and pt $\beta$-catenin protein are more active than wild-type $\beta$-catenin protein in the axis rescue assay (Fig. $2 \mathrm{C}$; data not shown), indicating that the differences in accumulation of wild-type and mutant $\beta$-catenins are caused by differences in the stability of the protein. We propose that Xgsk-3 functions to increase the degradation of $\beta$-catenin, thereby decreasing its steady-state levels. This is confirmed in an experiment in which expression of dominant-negative Xgsk-3, which mimics a Wnt signal by interfering with the endogenous Xgsk-3, increases the accumulation of wildtype $\beta$-catenin but does not alter the levels of mutant $\beta$-catenin. In accordance with our hypothesis, phosphorylation of $\beta$-catenin by Xgsk-3 creates an unstable form of the protein that is rapidly turned over in the cell.

Our results regarding the stability of $\beta$-catenin closely parallel those observed in Drosophila. Analysis of armadillo phosphorylation in Drosophila mutant embryos has shown that wingless signaling, which acts to repress $z w 3 /$ shaggy, decreases the phosphorylation of armadillo, whereas zw3/shaggy promotes the phosphorylation of armadillo (Peifer et al. 1994a). Complementary studies in Drosophila tissue culture cells have shown that wingless increases the levels of armadillo polypeptide by reducing the turnover of the armadillo protein (van Leeuwen and Nusse 1994). In our experiments, inhibition of the zw3/ shaggy homolog Xgsk-3 increases the accumulation of the armadillo homolog $\beta$-catenin, most likely by increasing protein half-life, suggesting that the phosphorylation of $\beta$-catenin results in increased protein turnover. These results indicate that not only are the components of the wingless pathway conserved between vertebrates and invertebrates, but the mechanism of $\beta$-catenin/armadillo regulation has been maintained.

A recent study in cultured cells has indicated that the adenomatous polyposis coli protein (APC) exists in a complex with $\beta$-catenin and GSK-3 (Rubinfeld et al. 1996). This is of interest because APC has been shown to down-regulate $\beta$-catenin levels when expressed ectopically in colon cancer cells that contain a mutant form of APC (Munemitsu et al. 1995). Furthermore, in vitro phosphorylation of APC by a combination of protein kinase A and GSK-3 causes APC to bind more effectively to $\beta$-catenin in vitro, suggesting that one role of GSK-3 is to promote the association of $\beta$-catenin and APC (Munemitsu et al. 1995). These results do not explain why $\Delta \beta$ catenin or pt $\beta$-catenin are more stable than wild-type $\beta$-catenin, because deletion of the amino terminus of $\beta$-catenin does not decrease the association of APC and $\beta$-catenin in vivo (Hulsken et al. 1994). Our results suggest that the phosphorylation of $\beta$-catenin at the aminoterminal site by Xgsk-3 is a requisite step in promoting its degradation. We do not rule out the possibility that the amino-terminal site we have identified is required for the interaction of $\beta$-catenin with another protein or with GSK-3-phosphorylated APC in a phosphorylationindependent manner as part of the degradation mechanism. This possibility, however, does not explain why wild-type $\beta$-catenin is phosphorylated more heavily in vivo in a Xgsk-3-dependent manner than is pt $\beta$-catenin. Instead, we suggest that Xgsk-3 phosphorylates wildtype $\beta$-catenin in vivo, leading to its rapid degradation.

\section{Nuclear localization of $\beta$-catenin}

A previous study has shown that injection of RNA encoding $\beta$-catenin leads to the nuclear accumulation of ectopic $\beta$-catenin (Funayama et al. 1995), although this investigation did not address the localization of endogenous $\beta$-catenin nor its potential regulation by Xgsk-3. In the present study, we report that endogenous $\beta$-catenin in intact animal caps of gastrula-stage embryos is localized at both the plasma membrane and in many nuclei. If the nuclear distribution were physiologically relevant with respect to the role of $\beta$-catenin in a Wnt signaling pathway, one prediction is that either the steady-state level or the signaling activity of the nuclear $\beta$-catenin might be modulated by Xgsk-3. Consistent with this possibility, we report that the relative level of $\beta$-catenin in the nucleus compared with that in the plasma mem- 
brane is enhanced by the expression of the dominantnegative mutant of Xgsk-3 (Fig. 5; Table 2). Although these experiments do not address the functional significance of the nuclear $\beta$-catenin, it is intriguing to consider that the amount of $\beta$-catenin in the nucleus may regulate the level of dorsal gene expression.

We predict that there should be some dorsal-ventral difference in the levels or the nuclear/membrane ratio of $\beta$-catenin, because we have demonstrated that Xgsk-3 decreases $\beta$-catenin stability and concomitantly modulates its subcellular distribution, and because previous studies are consistent with dorsal-ventral differences in Xgsk-3 activity in Xenopus embryos (Dominguez et al. 1995; He et al. 1995; Pierce and Kimelman 1995). Fagotto and Gumbiner (1994) have measured the levels of total $\beta$-catenin in dorsal and ventral halves of embryos and observed no obvious differences. We expect that $\beta$-catenin may be at increased levels in only a small region of the embryo, however, corresponding to the future dorsal vegetal region, and assays of total $\beta$-catenin levels in half the embryo could easily obscure this effect. Second, there may be differences in the amounts of $\beta$-catenin in nuclei or at the plasma membrane that are physiologically relevant to determining the dorsal-ventral axes but that could be obscured by measurements of total $\beta$-catenin levels. In light of the above arguments, we have attempted to compare the levels of nuclear $\beta$-catenin in the dorsal and ventral vegetal regions of the early embryo. Unfortunately, the autofluorescence of the large early vegetal cells has thus far prevented an analysis of the level of the subcellular distribution of $\beta$-catenin in this region of the embryo.

Finally, in oligonucleotide depletion experiments, Heasman et al. (1994) have shown that maternal $\beta$-catenin RNA is required for dorsal axis formation, but the detectable maternal $\beta$-catenin protein still present in their experiments raises the question of whether only $\beta$-catenin newly synthesized from the maternal (and oligonucleotide-sensitive) RNA is involved in specification of the embryonic axes. If this occurred, Xgsk-3 may only regulate the stability and distribution of the $\beta$-catenin that is translated from maternal RNA after fertilization, whereas the distribution of stored maternal $\beta$-catenin protein may be unregulated as a result of its being inaccessible for phosphorylation or degradation, perhaps owing to association with cadherins and $\alpha$-catenin. Thus, the levels of $\beta$-catenin translated after fertilization of the egg may be critical, whereas the absolute levels of $\beta$-catenin may not be relevant to dorsal axis formation.

\section{Summary and model}

The data presented here and elsewhere (Dominguez et al. 1995; He et al. 1995; Pierce and Kimelman 1995) are consistent with the hypothesis that the postfertilization rotation of the cortex of the Xenopus egg causes some of the future dorsal vegetal region to have a level of Xgsk-3 activity, which is less than on the future ventral side. In response to these spatial differences in activity of Xgsk3 , which may come about either through signaling by a maternal Wnt (for review, see Cui et al. 1995) or through a ligand-independent manner, newly synthesized or preexisting $\beta$-catenin will be regulated with respect to both steady-state level and subcellular distribution. In this model the future dorsal region will have less phosphorylated $\beta$-catenin than in the rest of the embryo, and as a consequence, the nonphosphorylated $\beta$-catenin may accumulate to greater levels in a specific subcellular location such as the nucleus, leading to the specification of a dorsal axis (Fig. 6). In the remainder of the embryo, Xgsk-3 functions to phosphorylate $\beta$-catenin (and APC), keeping it from acting as a dorsalizing agent.

The testing of this model requires the direct measurement of spatial differences in Xgsk-3 activity, as well as calculating spatial differences in $\beta$-catenin levels and subcellular distribution. Our demonstration that Xgsk-3 directly phosphorylates $\beta$-catenin and modulates its stability and subcellular distribution should contribute to the long-standing issue of how the dorsal-ventral axis is established.

\section{Materials and methods}

$\beta$-catenin constructs

A $\beta$-catenin cDNA encoding the full coding sequence was isolated from Xenopus embryos by use of reverse transcriptase and the polymerase chain reaction (PCR) with Vent polymerase (New England Biolabs). $\Delta \beta$-catenin was generated similarly by
+ Xgsk-3
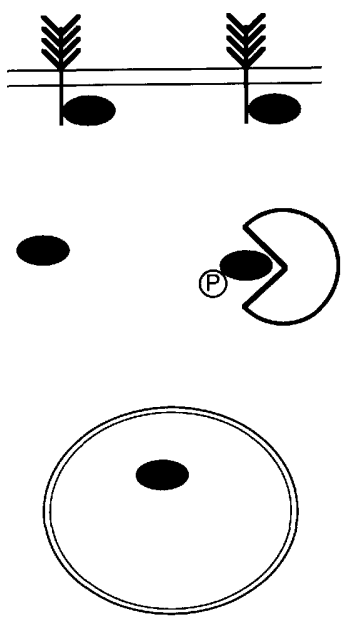

-Xgsk-3
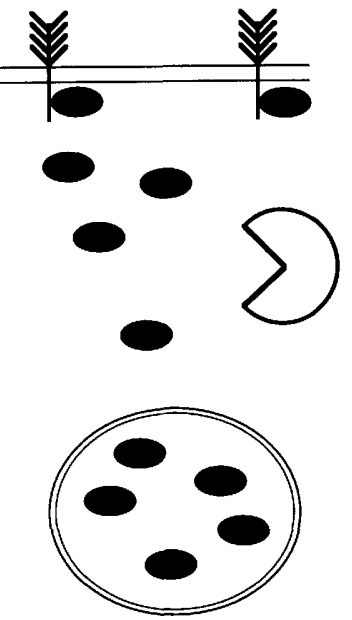

Figure 6. Model for $\beta$-catenin regulation by Xgsk-3. In the presence of Xgsk-3, $\beta$-catenin is phosphorylated at the amino-terminal site, which causes it to be rapidly degraded. This leads to a lower level of $\beta$-catenin in the cytoplasm and in the nucleus. When Xgsk-3 activity is reduced in response to Wnt signaling, or in the presence of a dominant negative Xgsk-3, $\beta$-catenin is not as highly phosphorylated and is therefore not rapidly degraded. This leads to higher levels of $\beta$-catenin in the cytoplasm and in the nucleus. Some aspects of this model are similar to that proposed for the regulation of armadillo by the wingless signaling pathway in Drosophila (Peifer et al. 1994a). 
PCR resulting in the insertion of a new initiation codon after the first 47 amino acids. pt $\beta$-catenin was generated by PCR with overlapping oligonucleotides to produce the amino acid substitutions shown in Figure 1A. All cDNAs were cloned into the vectors CS2+MT (D. Turner, R. Rupp, and H. Weintraub, Fred Hutchinson Cancer Research Center, Seattle, WA), which added a c-myc epitope at the carboxy-terminal end of the $\beta$-catenins, and pQE30 (Qiagen) to produce histidine-tagged proteins.

\section{In vitro kinase assays with recombinant proteins}

A histidine-tagged fusion protein of Xgsk-3-thioredoxin [trx) was produced in E. coli by the insertion of Xgsk-3 cDNA (Pierce and Kimelman 1995) into the BamHI site of pETRX (J. Kulman, University of Washington, Seattle). Recombinant protein was purified on a nickel column (His-Bind resin, Novagen) following the manufacturer's instructions. Protein was dialyzed against $50 \%$ glycerol, $1 \mathrm{~mm}$ dithiothreitol (DTT), and $10 \mathrm{~mm}$ Tris $(\mathrm{at} \mathrm{pH}$ 7.5 and stored at $-20^{\circ} \mathrm{C}$. Histidine-tagged $\beta$-catenin, $\Delta \beta$-catenin, and pt $\beta$-catenin were expressed in $E$. coli by use of the expression vector $\mathrm{PQE} 30$, and proteins were also purified on the nickel column.

For in vitro kinase assays, $1 \mu \mathrm{g}$ of $\beta$-catenin, $\Delta \beta$-catenin, or $\mathrm{pt}$ $\beta$-catenin was diluted in $20 \mathrm{ml}$ of ice-cold protein kinase buffer containing $20 \mathrm{~mm}$ HEPES- $\mathrm{NaOH}$ ( $\mathrm{pH} 7.4), 10 \mathrm{~mm} \mathrm{MgCl}, 1 \mathrm{~mm}$ DTT, $80 \mathrm{~mm}$ ATP, and $50 \mu \mathrm{Ci}\left[\gamma^{-32} \mathrm{P} \mid \mathrm{ATP}(6000 \mathrm{Ci} / \mathrm{mmole})\right.$. Following a $15-\mathrm{min}$ incubation at $30^{\circ} \mathrm{C}$ with 1 unit of Xgsk-3trx, the samples were separated on a $10 \%$ SDS-polyacrylamide gel and Coomassie-stained, dried, and autoradiographed. One unit of kinase activity is defined as the amount of enzyme leading to the incorporation of $10 \mathrm{nmoles}$ of ${ }^{32} \mathrm{Pi} /$ per minute into GS1 peptide (Eldar-Finkelman et al. 1995).

\section{In vivo phosphorylation of $\beta$-catenin}

Stage 4-6 oocytes were isolated from Xenopus ovaries by collagenase A treatment (see Smith et al. 1991), followed by overnight incubation in $1 \times \mathrm{MMR}(0.1 \mathrm{M} \mathrm{NaCl}, 2.0 \mathrm{mM} \mathrm{KCl}, 1.0 \mathrm{~mm}$ $\mathrm{MgSO}_{4}, 2.0 \mathrm{~mm} \mathrm{CaCl}_{2}, 0.1 \mathrm{~mm}$ EDTA, 5.0 mM HEPES at pH 7.8) supplemented with bovine serum albumin at $13^{\circ} \mathrm{C}$. Oocytes were sorted into groups of 200 and injected with $7.5 \mathrm{ng}$ of RNA encoding Xgsk-3 and $3.5 \mathrm{ng}$ of either $\beta$-catenin or pt $\beta$-catenin RNA. In one experiment, 14 ng of dnXgsk-3 RNA was injected prior to injection of RNA encoding $\beta$-catenin and Xgsk-3. Injected oocytes were labeled with $1.6 \mathrm{mCi}$ of $\left[{ }^{32} \mathrm{P}\right]$-orthophosphate (New England Nuclear) in $1 \times$ MMR for $5 \mathrm{hr}$ at room temperature. Labeled oocytes were washed three times in $50 \mathrm{ml}$ of phosphate-buffered saline (PBS at $\mathrm{pH} 7.5$ ), and protein was extracted in lysis buffer $(10 \mathrm{mM}$ Tris, $150 \mathrm{mM} \mathrm{NaCl}, 2 \mathrm{~mm}$ EDTA, 2 mM EGTA, 1\% NP-40, 4 mM PMSF at pH 7.5) and 1,1,2-trichlorotrifluoroethane (Sigma). Ectopic myc-tagged wild-type and pt $\beta$-catenin were immunoprecipitated by use of the mouse monoclonal anti-myc antibody (Oncogene Science) and protein G-Sepharose beads (Sigma). To quantitate wild-type and $\mathrm{pt} \beta$-catenin protein levels, the immunoprecipitates were analyzed by SDS-PAGE and immunoblotting with the same anti-myc antibody followed by an HRP-conjugated goat antimouse secondary antiserum (Bio-Rad). HRP signal was visualized by ECL (Amersham). Relative amounts of wild-type and pt $\beta$-catenin protein levels were quantitated by use of densitometry (UA-5 Absorbance/Fluorescence detector, ISCO). Relative of ${ }^{32} \mathrm{P}$, incorporation into wild-type and $\mathrm{pt} \beta$-catenin was quantitated by PhosphorImager analysis (PhosphorImager model 400S, Molecular Dynamics) and then normalized for the amount of myc signal present on the anti-myc Western blot, with wildtype $\beta$-catenin ${ }^{32} \mathrm{P}$ incorporation set at $100 \%$.
Microinjection of synthetic RNAs and recombinant proteins into fertilized eggs

Xenopus embryos were fertilized in $0.5 \times$ MMR. The jelly coat was removed with $2 \%$ cysteine in water ( $\mathrm{pH} 7.8)$, and eggs were rinsed in $0.1 \times$ MMR. Embryos were treated with UV irradiation for $50 \mathrm{sec}$ within $40 \mathrm{~min}$ after fertilization (Gerhart et al. 1989). Embryos were kept at $14-23^{\circ} \mathrm{C}$ until stage 35 and then evaluated by the dorso-anterior index (DAI) score (Kao and Elinson 1988). RNAs for injection were synthesized by use of the SP6 mMESSAGE mMACHINE kit (Ambion) from pCS2 + MT-derived vectors linearized with NotI. RNA was microinjected (Moon and Christian 1989) into the ventral marginal zone of one blastomere of four- to eight-cell embryos, or UV-irradiated eggs, as indicated. Controls were injected with water or $\beta$-galactosidase RNA as indicated.

\section{Synthesis of proteins in reticulocyte extract and injection} into embryos

$\beta$-Catenin and pt $\beta$-catenin proteins were translated in a rabbit reticulocyte lysate supplemented with $\left.{ }^{35} \mathrm{~S}\right]$-methionine and programmed with RNAs transcribed by use of the Message Machine Kit (Ambion). Template RNA was then destroyed by the addition of RNase, followed by RNAsin (Promega) to inhibit RNase activity. Forty nanoliters of the reticulocyte lysate reaction was then injected into the animal pole of both blastomeres of two-cell-stage embryos. Protein was extracted from $40 \mathrm{em}$ bryos per sample, 0,1 , and $4 \mathrm{hr}$ after injection, using a nondenaturing extraction buffer $(10 \mathrm{mM}$ HEPES at $\mathrm{pH} 7.5,150 \mathrm{~mm}$ $\mathrm{NaCl}, 2$ mM EDTA, 2 mм EGTA, 1\% NP-40, 4 mM PMSF). Exogenous $\beta$-catenin and pt $\beta$-catenin proteins were immunoprecipitated with the anti-myc monoclonal antibody (Oncogene Science) and protein G 4B Fast Flow Sepharose beads (Sigma). Immunoprecipitated proteins were analyzed by SDS-PAGE, followed by treatment with Enhance (New England Nuclear) to amplify the ${ }^{35} \mathrm{~S}$ signal, and autoradiography with an intensifying screen.

\section{Western blot analyses to monitor ectopic $\beta$-catenin}

$\beta$-catenin, $\Delta \beta$-catenin, or $p t \beta$-catenin RNA ( $40 \mathrm{pg}$ ) was injected alone or in combination with frameshift hedgehog (fshh), Xgsk3 , or $d n X g s k-3$ RNA (120 pg) into the animal pole of one- to two-cell-stage nonirradiated or UV-irradiated embryos. Protein was extracted 4 or $8 \mathrm{hr}$ after injection using a nondenaturing buffer (10 mM HEPES at pH 7.5, $150 \mathrm{~mm} \mathrm{NaCl}, 2$ mM EDTA, 2 mM EGTA, 1\% NP-40, 4 mM PMSF). Protein samples from five embryos were analyzed by SDS-PAGE and immunoblotting with a mouse anti-myc monoclonal antibody /Oncogene Sciencel, followed by an HRP-conjugated goat anti-mouse secondary antiserum (Bio-Rad). The HRP signal was visualized by ECL (Amersham), and levels compared by densitometry.

\section{Fluorescence microscopy}

To monitor the localization of endogenous $\beta$-catenin, gastrula cap explants were stained with antibodies generated against a previously described (McCrea et al. 1993) $\beta$-catenin-GST fusion protein (1:1000 dilution), followed by a Cy-5-conjugated goat anti-rabbit secondary antibody (1:500). Explants were viewed on a Nikon FXA fluorescence microscope with a CY-5 filter and equipped with a Hammamatsu cooled CCD camera, which imported the 16-bit images into Metamorph 2.0 software (Universal Imaging Corp.). To determine whether nuclear fluorescence was greater or less than that of the cell membrane, the software 
was employed to set the threshold for fluorescence to that of the membranes. Cells were then counted from the video monitor with or without the threshold.

\section{Acknowledgments}

We thank the reviewers for comments on this manuscript, and Paul Polakis for sharing unpublished work. C.Y. was supported by U.S. Public Health Service Award GM 07270, E.H. was supported by HD29360 to R.T.M., and the work of C.Y. and D.K. was supported by HD27262 to DK. M.T. is a predoctoral fellow, J.R.M. a research associate, and R.T.M. an investigator of the Howard Hughes Medical Institute. We thank P. McCrea and B. Gumbiner for the GST fusion protein construct, H. EldarFinkelman for GSl peptide, and J. Kulman for pETRX.

The publication costs of this article were defrayed in part by payment of page charges. This article must therefore be hereby marked "advertisement" in accordance with 18 USC section 1734 solely to indicate this fact.

\section{References}

Bourouis, M., P. Moore, L.Y.G. Ruel, P. Heitzler, and P. Simpson. 1990. An early embryonic product of the gene shaggy encodes a serine/threonine protein kinase related to the CDC28/cdc2 ${ }^{+}$subfamily. EMBO J. 9: 2877-2884.

Boyle, J.B., T. Smeal, L. Defize, P. Angel, J. Woodgett, M. Karin, and T. Hunter. 1991. Activation of protein kinase C decreases phosphorylation of c-Jun at sites that negatively regulate its DNA-binding activity. Cell 64: 573-583.

Cui, Y., J.D. Brown, R.T. Moon, and J.L. Christian. 1995. $X w n t 8 b$ : A maternally expressed Xenopus Wnt gene with a potential role in establishing the dorso-ventral axis. Development 121: 2177-2186.

DeMarais, A. and R.T. Moon. 1992. The armadillo homologs $\beta$-catenin and plakoglobin are differentially expressed during early development of Xenopus laevis. Dev. Biol. 153: 337346.

Dominguez, I., K. Itoh, and S.Y. Sokol. 1995. Role of glycogen synthase kinase $3 \beta$ as a negative regulator of dorsoventral axis formation in Xenopus embryos. Proc. Natl. Acad. Sci. 92: 8498-8502.

Eldar-Finkelman, H., R. Seger, J.R. Vendenheede, and E.G. Krebs. 1995. Inactivation of glycogen synthase kinase- 3 by epidermal growth factor is mediated by mitogen-activated protein kinase/p90 ribosomal protein S6 kinase signaling pathway in NIH/3T3 cells. J. Biol. Chem. 270: 987-990.

Fagotto, F. and B. Gumbiner. 1994. $\beta$-catenin localization during Xenopus embryogenesis: Accumulation at tissue and somite boundaries. Development 120: 3667-3679.

Funayama, N., F. Fagotto, P. McCrea, and B.M. Gumbiner. 1995. Embryonic axis induction by the Armadillo repeat domain of $\beta$-catenin: Evidence for intracellular signaling. I. Cell Biol. 128: 959-968.

Gerhart, J.C., M. Danilchick, T. Doniach, S. Roberts, B. Rowning, and R. Stewart. 1989. Cortical rotation of the Xenopus egg: Consequences for the anteroposterior pattern of embryonic dorsal development. Development (Suppl.) 107: 37-51.

Guger, K.A. and B.M. Gumbiner. 1995. $\beta$-catenin has Wnt-like activity and mimics the Nieuwkoop signaling center in $\mathrm{Xe}$ nopus dorsal-ventral patterning. Dev. Biol. 172: 115-125.

He, X., J.-P. Saint-Jeannet, J.R. Woodgett, H.E. Varmus, and I. Dawid. 1995. Glycogen synthase kinase-3 and dorsoventral patterning in Xenopus embryos. Nature 374: 617-622.

Heasman, J., A. Crawford, K. Goldstone, P. Garner-Hamrick, B.
Gumbiner, P. McCrea, C. Kintner, C.Y. Noro, and C. Wylie. 1994. Overexpression of cadherins and underexpression of $\beta$-catenin inhibit dorsal mesoderm induction in early Xenopus embryos. Cell 79: 791-803.

Hulsken, J., W. Birchmeier, and J. Behrens. 1994. E-cadherin and APC compete for the interaction of $\beta$-catenin and the cytoskeleton. J. Cell Biol. 127: 2061-2069.

Kao, K.R. and R.P. Elinson. 1988. The entire mesodermal mantle behaves as Spemann's organizer in dorsoanterior enhanced Xenopus laevis embryos. Dev. Biol. 127: 64-77.

Karnovsky, A. and M.W. Klymkowsky. 1995. Anterior axis duplication in Xenopus induced by over-expression of the cadherin-binding protein plakoglobin. Proc. Natl. Acad. Sci. 92: 4522-4526.

Kelly, G.M., D.F. Erezyilmaz, and R.T. Moon. 1995a. Induction of a secondary embryonic axis in zebrafish following the overexpression of $\beta$-catenin. Mech. Dev. 53: 261-273.

Kelly, G.M., P. Greenstein, D.F. Erezyilmaz, and R.T. Moon. 1995b. Zebrafish wnt 8 and wnt $8 b$ share a common activity but are involved in distinct developmental pathways. Development 121: 1787-1799.

Klingensmith, J., R. Nusse, and N. Perrimon. 1994. The Drosophila segment polarity gene dishevelled encodes a novel protein required for response to the wingless signal. Genes \& Dev. 8: 118-130.

$\mathrm{Ku}, \mathrm{M}$. and D.A. Melton. 1993. Xwnt-11: A maternally expressed Xenopus Wnt gene. Development 119: 1161-1173.

Malacinski, G.M., J. Brothers, and H.-M. Chung. 1977. Destruction of components of the neural induction system of the amphibian egg with ultraviolet irradiation. Dev. Biol. 56: 24-39.

McCrea, P.D., W.M. Brieher, and B.M. Gumbiner. 1993. Induction of a secondary body axis in Xenopus by antibodies to beta-catenin. J. Cell Biol. 123: 477-484.

McMahon, A.P. 1992. The Wnt family of developmental regulators. Trends Genet. 8: 1-5.

McMahon, A.P. and R.T. Moon. 1989. Ectopic expression of the proto-oncogene int- 1 in Xenopus embryos leads to duplication of the embryonic axis. Cell 58: 1075-1084.

Moon, R.T. and J.L. Christian. 1989. Microinjection and expression of synthetic mRNAs in Xenopus embryos. Technique 1: 76-89.

Moon, R.T., R.M. Campbell, J.L. Christian, L.L. McGrew, J. Shih, and S. Fraser. 1993a. Xwnt-5A: A maternal Wnt that affects morphogenetic movements after overexpression in embryos of Xenopus laevis. Development 119: 97-111.

Moon, R.T., J.L. Christian, R.M. Campbell, L.L. McGrew, A.A. DeMarais, M. Torres, C.-J. Lai, D. Olson, and G.M. Kelly. 1993b. Dissecting Wnt signalling pathways and Wnt-sensitive developmental processes through transient misexpression anlyses in embryos of Xenopus laevis. Development (Suppl.): 85-94.

Munemitsu, S., B. Albert, B. Souza, B. Rubinfeld, and P. Polakis. 1995. Regulation of intracellular beta-catenin levels by the adenomatous polyposis coli (APC) tumor suppressor protein. Proc. Nat1. Acad. Sci. 92: 3046-3050.

Nikolakaki, E., P.J. Coffer, R. Hemelsoet, J.R. Woodgett, and L.H.K. Defize. 1993. Glycogen synthase kinase 3 phosphorylates Jun family members in vitro and negatively regulates their transactivating potential in cells. Oncogene 8: 833840.

Noordermeer, J., J. Klingensmith, N. Perrimon, and R. Nusse. 1994. dishevelled and armadillo act in the Wingless signalling pathway in Drosophila. Nature 367: 80-83.

Nusse, R. and H.E. Varmus. 1992. Wht genes. Cell 69: 10731087. 
Peifer, M., C. Rauskolb, M. Williams, B. Riggleman, and E. Wieschaus. 1991. The segment polarity gene armadillo interacts with the wingless signaling pathway in both embryonic and adult pattern formation. Development 111: 1029-1043.

Peifer, M., L.-M. Pai, and M. Casey. 1994a. Phosphorylation of Drosophila adherens junction protein armadillo: Roles for wingless signal and zeste-white 3 kinase. Dev. Biol. 166: 543-556.

Peifer, M., D. Sweeton, M. Casey, and E. Wieschaus. 1994b. Wingless signal and zeste-white 3 kinase trigger opposing changes in the intracellular distribution of armadillo. Development 120: 369-380.

Pierce, S.B. and D. Kimelman. 1995. Regulation of Spemann organizer formation by the intracellular kinase Xgsk-3. Development 121: 755-765.

Plyte, S.E., K. Hughes, E. Nikolakaki, B.J. Pulverer, and J. Woodgett. 1992. Glycogen synthase kinase-3: Functions in oncogenesis and development. Biochim. Biophys. Acta 1114: 147-162.

Riggleman, R., E. Wieschaus, and P. Schedl. 1989. Molecular analysis of the armadillo locus: Uniformly distributed transcripts and a protein with novel internal repeats are associated with a Drosophila segment polarity gene. Genes \& Dev. 3: 96-113.

Riggleman, R., P. Schedl, and E. Wieschaus. 1990. Spatial expression of the Drosophila segment polarity gene armadillo is posttranscriptionally regulated by wingless. Cell 63: 549560.

Rijsewijk, F., M. Schuermann, E. Wagenaar, P. Parren, D. Weigel, and R. Nusse. 1987. The Drosophila homolog of the mouse mammary oncogene int -1 is identical to the segment polarity gene wingless. Cell 50: 649-657.

Rothbacher, U., M.N. Laurent, I.L. Blitz, T. Watabe, J.L. Marsh, and K.W.Y. Cho. 1995. Functional conservation of the Wnt signaling pathway revealed by ectopic expression of Drosophila dishevelled in Xenopus. Dev. Biol. 170: 717-721.

Rubinfeld, B., I. Albert, E. Porfiri, C. Fiol, S. Munemitsu, and P. Polakis. 1996. Binding of GSK3b to the APC- $\beta$-catenin complex and regulation of complex assembly. Science 272: 1023-1026.

Scharf, S.R. and J.C. Gerhart. 1980. Determination of the dorsalventral axis in eggs of Xenopus laevis: Complete rescue of uv-impaired eggs by oblique orientation before first cleavage. Dev. Biol. 79: 181-198.

Siegfried, E., T. Chou, and N. Perrimon. 1992. wingless signaling acts through zeste-white 3, the Drosophila homolog of glycogen synthase kinase-3, to regulate engrailed and establish cell fate. Cell 71: 1167-1179.

Siegfried, E., E.L. Wilder, and N. Perrimon. 1994. Components of wingless signaling in Drosophila. Nature 367: 76-80.

Smith L.D., W. Xu, and R.L. Varnold. 1991. Oogenesis and oocyte isolation. Methods Cell Biol. 36: 45-58.

Sokol, S.Y., J. Klingensmith, N. Perrimon, and K. Itoh. 1995. Dorsalizing and neuralizing properties of $X d s h$, a maternally expressed Xenopus homolog of dishevelled. Development 121: $1637-1647$.

Theisen, H., J. Purcell, M. Bennett, D. Kansagara, A. Syed, and J.L. Marsh. 1994. dishevelled is required during wingless signaling to establish both cell polarity and cell identity. Development 120: 347-360.

van Leeuwen, F. and R. Nusse. 1994. Biological activity of soluble wingless protein in cultured Drosophila cells. Nature 368: 342-344.

Wieschaus, E. and R. Riggleman. 1987. Autonomous requirements for the segment polarity gene armadillo during Drosophila embryogenesis. Cell 49: 117-184. 


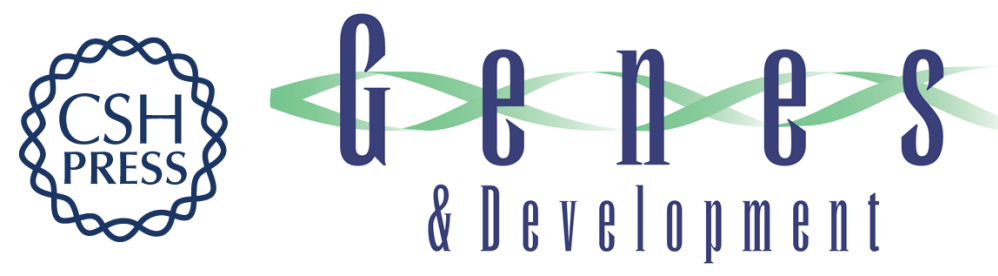

\section{The axis-inducing activity, stability, and subcellular distribution of beta-catenin is regulated in Xenopus embryos by glycogen synthase kinase 3.}

C Yost, M Torres, J R Miller, et al.

Genes Dev. 1996, 10:

Access the most recent version at doi:10.1101/gad.10.12.1443

References This article cites 46 articles, 21 of which can be accessed free at:

http://genesdev.cshlp.org/content/10/12/1443.full.html\#ref-list-1

License

Email Alerting

Service

Receive free email alerts when new articles cite this article - sign up in the box at the top right corner of the article or click here.

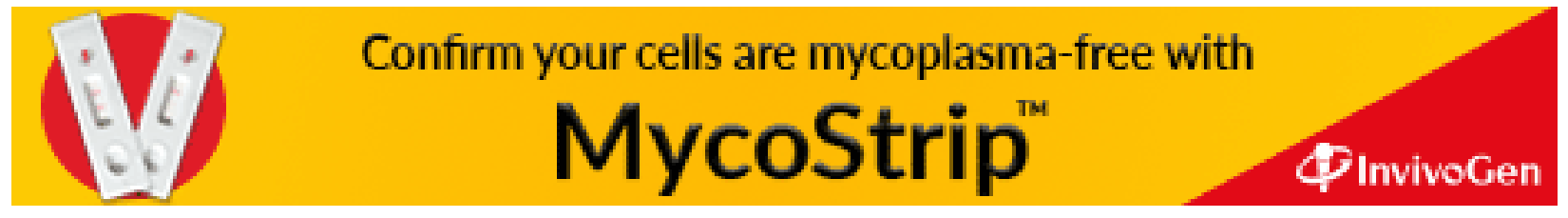

